\title{
Aquém do lulismo: notas críticas sobre a atual reprodução do paradigma do populismo por filósofos políticos brasileiros
}

Pedro Luiz Lima e Josué Medeiros

\author{
Pedro Luiz Lima \\ Professor de Ciência Política na \\ Universidade Federal do Rio de Janeiro. \\ E-mail: pedrollima@gmail.com \\ Josué Medeiros. \\ Professor de Ciência Política \\ na Universidade Federal do Rio de Janeiro. \\ E-mail: josuedsrj@yahoo.com.br
}

\begin{abstract}
Resumo
Consolidou-se entre alguns dos mais relevantes intérpretes do pensamento político brasileiro uma tendência analítica de retomar formas de caracterização antes aplicadas à República de 1946 para dar conta dos governos do PT desde 2003. Tornou-se frequente a analogia histórica entre os dois períodos como eixo interpretativo do presente, o que alçou mais uma vez a controversa noção de "populismo" ao status de conceito determinante para a apreensão da realidade. Delimitar o significado da retomada do que chamamos de paradigma do populismo nas obras de alguns dos expoentes locais da teoria crítica é o objetivo deste artigo. Sua circunscrição ao âmbito da filosofia política implica investigar como o "populismo" se imiscui mesmo ali onde o apuro no uso dos conceitos é mais pronunciado, como nas obras dos filósofos Vladimir Safatle, Paulo Arantes e Ruy Fausto. Argumenta-se que a persistência de pressupostos fundamentais do paradigma do populismo na análise dos filósofos dificulta, em vez de potencializar, a compreensão das efetivas contradições do fenômeno lulista.
\end{abstract}

\section{Palavras-chave}

Lulismo; Populismo; Filosofia política; Demofobia. 


\section{Introdução}

Desde muito antes do golpe parlamentar de 2016, consolidou-se entre alguns dos mais relevantes intérpretes da história do pensamento político brasileiro, à esquerda e à direita, uma tendência analítica de retomar formas de caracterização antes aplicadas à República de 1946 para dar conta dos governos do PT desde 2003. Tornou-se, assim, quase um senso comum adotar a analogia histórica entre os dois períodos como eixo interpretativo do presente, o que alçou mais uma vez a controversa noção de "populismo" ao status de conceito determinante para a apreensão da realidade. $O$ significado da retomada do que chamamos de paradigma populista, em sua angulação pela esquerda, é o objeto deste artigo. Antes, contudo, de o abordarmos diretamente, tomaremos breve atalho por aquele que é o ponto de partida conceitual mais mobilizado pelos críticos marxistas do populismo.

Nas primeiras páginas de $O 18$ Brumário de Luís Bonaparte, Marx aborda precisamente a questão da repetição histórica - e dos riscos que cercam a representação do presente em termos do passado. Não raro, a célebre frase sobre os fatos e personagens histórico-mundiais (weltgeschichtlichen) que aparecem uma vez como tragédia, e a segunda como farsa, é desvinculada de seu componente crítico por leitores marxistas: afirmar que Hegel "esqueceu" de acrescentar essa diferenciação, como o faz Marx, implica contestar a ideia mesma da repetição na história. A "farsa" esconderia uma realidade histórica, cuja singularidade objetiva se faz acompanhar contraditoriamente de um apego subjetivo ao passado, e residiria na prática corrente de adotar representações antigas para tratar de fatos e atores novos. Esse detalhe é importante para a sequência deste artigo: a "farsa" não se inscreve diretamente na prática concreta dos atores históricos, mas sim na representação, que eles próprios ou quaisquer outros sujeitos, configuram a respeito do tempo histórico em questão. Isso se evidencia quando a "farsa" passa a ser tratada como "pesadelo", no parágrafo seguinte, afinal é "sobre o cérebro dos vivos" que "a tradição de todas as gerações mortas pesa como um pesadelo". (Marx, 2011: 25). É através desse pesadelo que os homens fazem sua própria história, e não "por livre e espontânea vontade" (aus freien Stücken) ele se instala nesse hiato entre o fazer e o querer, amarrando o presente ao passado. Perceba-se ainda que na figura do pesadelo a falsa oposição entre tragédia e farsa se dilui, posto que ele é farsesco e trágico a um só tempo.

Há algo de necessário nessa farsa-pesadelo, mas não se deve perder de vista que nela há também algo de enganoso. Por um lado, o peso da tradição impõe-se e faz com que mesmo em "épocas de crise revolucionária" se recorra frequentemente a uma "linguagem emprestada" (erborgten Sprache) a fim de "representar as novas cenas da história mundial". (Marx, 2011: 25-26). Por outro lado, Marx é assertivo ao afirmar que "a revolução social do século XIX não pode retirar sua poesia do passado, mas apenas do futuro". (Marx, 2011: 28). A alusão ao universo linguístico é ilustrativa do fato de que a liberdade exige um desprendimento - a linguagem emprestada pode apenas deformar o novo, fazendo dele atualização caricata de um passado de que ainda não se consegue emancipar. A "poesia do futuro" é a expressão de uma linguagem afeita ao novo:

uma pessoa que acabou de aprender uma língua nova costuma retraduzila o tempo todo para sua língua materna; ela, porém, só conseguirá apropriar-se do espírito da nova língua e só será capaz de expressar-se livremente com a ajuda dela quando passar a se mover em seu âmbito sem reminiscências do passado e quando, em seu uso, esquecer a sua língua nativa (Marx, 2011: 26).

Capturar o "espírito da nova língua" e expressar-se com fluência através dela envolve uma penosa superação: é quase instintiva a tendência de confortar-se com a repetição e manter-se refém de seus termos familiares. Farsa, pesadelo e caricatura aparecem, em Marx, como figuras da "superstição com relação ao passado" que é preciso superar, não apenas na atividade revolucionária imediatamente prática, como também na interpretação histórica - até porque, como se sabe, essa divisão é, em si mesma, falsa.

Do âmbito hegeliano da "história mundial" para os parâmetros mais acanhados de nossa história local contemporânea, nossa hipótese nesse artigo é que diversas interpretações recentes da política brasileira na chave do "populismo", anguladas pela esquerda, utilizam-se de uma "linguagem 
emprestada" para conceituar o assim chamado "período lulista" (2003-2016). Residiria aí uma crônica e difusa limitação analítica para tratar do período. Trata-se, ademais, de dupla tragédia: a reapropriação do paradigma do populismo remonta a uma caracterização parcial e amplamente contestada do período democrático de 1946-1964, de modo que a reemergência de um antipopulismo de esquerda naturaliza sua avaliação sobre o Golpe de 1964 e a transplanta para o presente, entendido como mera repetição farsesca. Alimenta-se, assim, a incompreensão sobre a atual conjuntura com a reprodução acrítica de um estranho caso de paradigma interpretativo marxista cuja vitória histórica transcende, em muito, os ambientes da esquerda.

O esforço empreendido nesse artigo é parte de pesquisa mais abrangente que visa a desenvolver os meandros conceituais de algumas reedições contemporâneas do paradigma do populismo, cujas perspectivas se ancoram no presente a partir da enfática reiteração de seu consagrado olhar sobre o passado. Limita-se, pois, o presente trabalho a uma crítica conceitual de algumas das atualizações do paradigma. Mais especificamente, trata-se de recuperar o sentido de alguns usos da noção de populismo no âmbito do que poderíamos chamar de teoria crítica brasileira. Ainda que as interpretações do Brasil contemporâneo que trabalham com o enquadramento do populismo apresentem grande variedade interna e transbordem as rígidas fronteiras disciplinares, nosso recorte aqui incluirá apenas a análise de obras dos mais proeminentes expoentes da filosofia política. Esta circunscrição de nosso objeto visa a salientar que a reprodução, por vezes inadvertida, do paradigma do populismo se imiscui mesmo naquelas obras onde o apuro no uso dos conceitos é mais pronunciado. Nesse sentido, serão abordadas aqui as interpretações dos filósofos Vladimir Safatle, Paulo Arantes e Ruy Fausto - e caberá notar a forma pela qual, com o zelo conceitual próprio da filosofia política, os três, tácita ou deliberadamente, analisam criticamente o período lulista utilizando-se de conceitos, noções e premissas que remontam à clássica crítica marxista do populismo dos anos 1960.

Devido aos limites deste artigo, em vez de proceder a extensa reconstrução do momento fundador do paradigma, cabe aqui apenas indicar seus pressupostos mais determinantes. Entendemos que a análise de Francisco Weffort sobre o populismo é atravessada por algumas premissas que fazem sobressair a valência negativa de sua tentativa de interpretação dialética da história política do Brasil entre 1930 e 1964. Este viés, manifesto na linguagem amplamente empregada nos seus textos, o impediria de reconstituir no plano da análise as contradições concretas da vida política do país. E, o que é mais grave, levaria a uma espécie de sublimação do nervo conflitivo da luta política que culmina com o golpe de 1964. Há três pressupostos fundamentais que persistirão, em maior ou menor escala, nas críticas contemporâneas do populismo e que podem ser assim nomeados: a) pressuposto da classe como o sujeito político verdadeiro; b) pressuposto da conciliação como engodo; c) pressuposto teleológico do colapso necessário. Vejamos, pois, se e como estes elementos reaparecem em célebres interpretações de filósofos políticos acerca da natureza do fenômeno lulista.

\section{Lulismo e populismo segundo Safatle, Arantes e Fausto}

Para apreendermos o sentido das novas incorporações do "populismo" nas análises de conjuntura referentes ao período lulista (2003-2016), é evidente que atestar o uso do vocábulo figura como condição necessária, mas não suficiente. Interessará, portanto, partir da imediata identificação das reapropriações da noção de populismo para, em seguida, efetuar uma reconstrução que determine os fundamentos comuns que nos permitam compreender os novos críticos do populismo aqui estudados na chave da repetição de uma "linguagem emprestada". Estabelecer esse vínculo não pressupõe que o empréstimo se dê conscientemente ou através de adesão expressa dos autores contemporâneos à linhagem original dos formuladores do paradigma do populismo.

Com efeito, a reprodução do discurso pode ser, eventualmente, tanto mais significativa quanto menos óbvia parecer a filiação de seus novos portadores. Sob estas ressalvas, analisaremos alguns textos e falas de Vladimir Safatle e de Paulo Arantes, escritos e pronunciados ao longo do período lulista e em seu momento terminal, a fim de depreender os caracteres gerais e as implicações de uma interpretação do Brasil que compartilha amplamente os pressupostos do paradigma do populismo. A despeito de ocasionais diferenças de abordagem entre os autores, partese de um tratamento comum de suas posições com o objetivo de ressaltar a construção/reprodução de uma mesma matriz analítica da política brasileira. Interessa, ademais, que essa matriz compareça 
nas análises destes intérpretes, ambos vinculados à mesma escola uspiana de filosofia. Também por esta razão, serão brevemente analisados, ao fim desta seção, alguns recentes comentários de Ruy Fausto sobre a política nacional, por assinalarem, ainda uma vez, a persistência da matriz do populismo no discurso filosófico-político da crítica, pela esquerda, aos governos petistas.

Se ambos, Safatle e Arantes, utilizam-se largamente da noção de populismo para caracterizar o período lulista, importa de partida perceber que o primeiro se mostra, por vezes, relativamente desconfortável com essa reapropriação terminológica. Este desconforto se revela em dois planos, seja no âmbito conceitual, pelo imperativo de distinguir o conceito do mero vocábulo pejorativo, seja no âmbito histórico - e nos dois planos pode-se notar como o filósofo luta contra uma imprecisão que, renitente, permanece em seus escritos.

Safatle afirma que "o conceito de 'populismo' existe e não é apenas um dispositivo de desqualificação política, embora muitas vezes seja usado apenas para isso" (2012:57), modo pelo qual espera resguardar-se da contaminação por usos pouco rigorosos do termo. Ocorre, porém, que "existir" não faz com que o "conceito" transcenda o plano de disputas políticas em que ele há muito se inscreve, e a dificuldade de uma amarração conceitual precisa do termo se manifesta nos próprios escritos de Safatle. Ora o termo é definido no sentido liberal clássico, como "um governo profundamente personalista e centralizado cuja figura do mandatário do Executivo encarna o ideal de condução e, por isso, confunde-se com a figura do poder" (2012:57); ora mais próximo às teorizações de Ernesto Laclau, quando rechaça a "polaridade entre democracia com instituições fortes e autoritarismo personalista" como mero componente da instrumentalização conservadora do termo (2016a:84). Entre a adesão e a crítica à vinculação entre personalismo e populismo, que é por ele caracterizada como conservadora; entre a adesão e a crítica à conceituação democratizante de Laclau - é sobre esta ambivalência de fundo que Safatle se utiliza do populismo.

No plano histórico, a oscilação passa a ser ainda mais expressiva. Por um lado, "há algo de piada de mau gosto na afirmação de que o Brasil conheceu, entre 1945 e 1964, uma 'república populista'. Só mesmo uma historiografia revisionista, que visa a desqualificar o único momento na história brasileira em que a participação popular foi efetiva, poderia dizer algo dessa natureza" (2012:57). Mas esta veemente recusa do epíteto populista para tratar da República de 1946 convive, em outros textos do filósofo, com uma mais frequente adesão irrestrita ao senso comum historiográfico segundo o qual tratou-se do "período populista" da história do país. E o desdém às potencialidades democráticas do regime de 1946 condiciona, nos novos críticos do populismo, uma perspectiva sobre o período lulista que tende a combinar uma leitura histórica na dupla chave da continuidade perversa e da repetição dos desvios com uma leitura política que minimiza a relevância da democracia representativa.

Nesse sentido, chega-se a afirmar que toda a história do Brasil "funcionou até hoje sob um pêndulo", em cujo movimento se inscreveria a gravosa realidade de que "tudo o que conseguimos produzir contra o cinismo das oligarquias foi a reincidência contínua do populismo" (2016b). Na contramão, portanto, do ensinamento marxiano de $O$ Dezoito Brumário acerca das aparências deceptivas das repetições históricas, aqui elas são entendidas por seu valor de face, de modo que "todos os atores políticos" transformam-se "em repetições de atores passados" em "um país no qual o passado nunca passa" (2016b). Nesta história cíclica, certamente mais trágica do que a polibiana, posto que oscilante entre duas formas perversas de governo, "o lulismo no poder" nada mais seria do que a "reincorporação dessa lógica populista" (2016b). A despeito dos incômodos preliminares com a manipulação do conceito de populismo, nota-se que uma vez posto em prática, o populismo reaparece na perspectiva política de Safatle com os mesmos ônus de sempre, tributário de uma interpretação macrohistórica pouco afeita a nuances políticas. Descartados aqueles sintomáticos cuidados conceituais, o mesmo se percebe na leitura de Paulo Arantes.

Acompanhar a obra de Arantes produzida desde o início do governo Lula, em 2003, é seguir uma narrativa absolutamente monotemática acerca da repetição. Não haveria nada de novo sob o sol, sob nenhuma hipótese, tornando-se o filósofo um cronista da persistência atávica de formas perversas de dominação. $E$ um dos frequentes marcadores da continuidade residiria na reiteração do populismo. Assim é que o "populismo lulista" não passaria, desde 2005, de "um populismo raso, ancorado no marketing de uma biografia que já é passado" (Arantes, 2007:227 e 260). Com sua peculiar retórica, que empresta tons ainda mais carregados a uma história que se inscreve em horizonte similar àquele concebido por Safatle, Paulo Arantes corrobora "a sensação de que o país anda em círculos" (Arantes, 2007:221). Viveríamos, por aqui, "o longo inverno de nossa 
despolitização" (Arantes, 2007:274), que se iniciaria pouco antes da Assembleia Constituinte de 1987-1988. Concedida esta pequena abertura histórica entre as greves de 1979 e a campanha pelas eleições diretas de 1984, apenas restaria, para além disso, a monotonia da dominação.

A afirmação de uma "irrelevância da política", quando não do próprio "fim da política" (Arantes, 2007:253), aparece na perspectiva de Arantes como radicalização de um princípio comum, nos "novos críticos do populismo", de desvalorização da rotina eleitoral como mera dissimulação oligárquica. Por isso aquele "longo inverno de despolitização" pode ser diagnosticado precisamente a partir do momento da retomada da participação eleitoral em nível nacional. Arantes despreza, sem meias palavras, a prática da competição eleitoral, o que o leva a empurrar a própria noção de democracia para o valão comum das inutilidades anacrônicas, em passagem que cumpre citar na íntegra. Para ele, viveríamos

num ambiente social e político muito além do pas de deux envelhecido Democracia e Ditadura. Vivemos fora do museu onde esses trastes podem ser visitados e apreciados na sua justa medida: Liberalismo (político ou econômico), Social-Democracia, Democracia Participativa (seção Últimas Aquisições), sem falar num outro museu, o da Revolução, a ser frequentado mais assiduamente, é verdade. É onde vivemos, numa ordem que poderia ser redescrita como ademocrática (...), onde não faz mais o menor sentido contrapor a democracia liberal de nossos avós ao fantasma de um autoritarismo neoliberal. Enquanto a esquerda não se livrar desse entulho, nada terá a dizer a não ser chorar o leite derramado, que aliás nunca foi o seu (Arantes, 2014:452).

Veremos, mais adiante, as implicações que guarda esta concepção de uma ordem "ademocrática" no contexto do golpe parlamentar de 2016. Por ora, importa salientar que o vínculo entre esta adoção do populismo como categoria explicativa e a desvalorização da democracia brasileira, apanágios de uma leitura indiferenciada da história da Nova República, é também recorrente na interpretação de Safatle. Não é outro, por exemplo, o tom com que o filósofo afirma que a "nossa derrota vem de longe, nossa derrota vem de 1984" (2016c). O mesmo "longo inverno de despolitização" tematizado por Arantes agora reaparece como a longínqua derrota em Safatle, para quem "a Nova República foi um dos momentos de maior covardia política da história brasileira" (2016c).

Se, por um lado, o paradigma do populismo tende a inscrever a história política em um estrito balizamento estrutural, manifesto em sua ênfase dos limites estruturais e do colapso necessário do modelo populista; por outro lado, há também o momento voluntarista desta concepção, que transparece na assunção da "covardia política" como uma variável de análise. O alvo prioritário é a conciliação, que tratada em chave voluntarista torna-se, nos termos de Safatle, "covardia", "capitulação", "rendição" e "acomodação".

Seu diagnóstico sobre os primeiros momentos da Nova República, a despeito das inúmeras conquistas incorporadas na Constituição Cidadã de 1988, é flagrantemente unilateral: tratou-se de "uma verdadeira capitulação das forças democráticas a um modelo de conciliação política que serviu para paralisar todo o ímpeto mais profundo de mudança" (Safatle, 2016c). Neste quadro, o PT representaria apenas "mais um ator na grande história da Conciliação Nacional", cuja "rendição" residiria, em última instância, no fato de que "Lula realizou de forma mais acabada o modelo [de conciliação]" ao transpor "para dentro do Estado todos os conflitos da sociedade civil" (2016c). Teríamos, por fim, com o lulismo, a "acomodação final da esquerda nacional a uma semidemocracia imobilista" (Safatle, 2012:14) - e resta fora de dúvida a incompatibilidade que se estabelece entre populismo e uma noção de democracia sem adjuntos desabonadores. Acomodada, rendida e conciliada, a esquerda nacional teria legitimado e reproduzido esta semidemocracia imobilista, forma anômala de imposição de desvios na realização do princípio da soberania popular.

Não por acaso, as interpretações de Safatle e Arantes sobre a atuação do Estado no período lulista aproximam-se de temas consagrados da interpretação liberal do Brasil, malgrado sua inscrição intencional no campo da esquerda radical - assim como a crítica do populismo, pela esquerda, tende a repor conteúdos próprios da luta política travada entre a direita conservadora e o suposto líder populista. Safatle identifica no lulismo a recuperação do "projeto de um verdadeiro capitalismo de Estado brasileiro, retomando um modelo protokeynesiano existente no país, durante os anos $1950 \mathrm{e}$ 1960, sob o nome de 'nacional-desenvolvimentismo'"' (Safatle, 2015:72). Adjetivos pejorativos à 
parte, trata-se da apreensão acertada de um traço marcante na relação do lulismo com a tradição trabalhista da história política nacional.

Mas assim como o "nacional-desenvolvimentismo" originário marcharia, nos caminhos definidos pela formulação original do paradigma do populismo, necessariamente para o colapso, também o lulismo entendido como mera repetição tardia daquele modelo também rumaria para encontrar seus limites estruturais intrínsecos, aqui identificados pela política de "fortalecimento do mercado interno pela introdução de massas de cidadãos pobres no universo de consumo" (Safatle, 2015:73). Enfatizando o consumo e o mercado como terrenos limitados para a incorporação dos mais pobres, e tratando como antitéticas as criticadas "políticas de capitalização da classe mais pobre" e as desejadas "políticas de combate à desigualdade" (Safatle, 2015:73-4), Safatle questiona o "capitalismo monopolista de Estado" promovido pelo lulismo em termos análogos àqueles que encontraremos, por exemplo, em textos recentes de Fernando Henrique Cardoso contra o que qualifica como "lulopetismo" (2015). O crítico contumaz da "capitalização da pobreza" e da "inclusão via consumo" adere ao diagnóstico que defende a necessidade de ampliação do número dos agentes econômicos no mercado, contra "os processos de oligopolização e cartelização da economia" (Safatle, 2015:75) alimentados pelo capitalismo monopolista de Estado.

Também no caso desta afinidade de fundo entre a crítica radical do populismo e interpretações do Brasil em chave liberal, Paulo Arantes irá manifestar em termos claríssimos aquilo que em Safatle permanece, no mais das vezes, nas entrelinhas. Sua inscrição da história recente do Brasil numa grande narrativa da continuidade imaculada da dominação não poderia prescindir da alusão ao mais célebre intérprete deste "longínquo pesadelo brasileiro" (Lessa, 2002): Raymundo Faoro. Nesta chave, o PT não ambicionaria, desde o início do primeiro governo Lula, nada além de "ingressar no condomínio patrimonialista brasileiro" (Arantes, 2007:255). Arantes chega a tratar de um "neopatrimonialismo petista", que, carente de atributos próprios e de projetos propriamente ditos, seria "idêntico ao velho Estado patrimonial estudado por Raymundo Faoro" (Arantes, 2007:282).

Bem entendida, nos termos de Safatle e Arantes, a repetição do populismo tende a esbarrar, desde o seu início, em limites intransponíveis. E a concepção de um "modelo populista" induz à ideia de que o colapso seria apenas a conclusão necessária desta já tão conhecida narrativa. "Tudo isso tinha um prazo de validade", diz-nos Safatle, e "qualquer pessoa poderia perceber que o crescimento provocado pelo lulismo tinha limites claros" (2016c). Esta pressuposta objetividade dos limites, afirmada depois da derrubada do governo do PT em 2016, soa como a identificação a posteriori de uma tendência já realizada pela história - assim como a originária formulação do paradigma do populismo havia teorizado os limites de um modelo, em grande medida, depois de sua derrota política. Importa aqui salientar que esta noção de limites objetivos de um suposto "modelo populista" é corolário daquela concepção reducionista da política e da democracia que acompanhamos acima. Mesmo antes do golpe de 2016, Safatle já teorizava sobre os "limites do modelo brasileiro", sobre um "desenvolvimento econômico irrealizável" e sobre "um processo de acumulação que tende a eliminar, em um rápido espaço de tempo, as conquistas no combate à desigualdade" (Safatle, 2015:73,74,75).

Tais análises, antes de meramente confirmar o eventual acerto dos pressupostos pelo subsequente desencadear de acontecimentos, revelam a estrutura de uma forma de pensar a política que tende a reificar "modelos", com seus "limites necessários" e tendências inexoráveis ao "colapso" - forma reducionista por excelência, que nos parece inapta a capturar as especificidades da história e as nuances e virtualidades da política, submetendo-as à estrita dinâmica de faits accomplis. Isto, que talvez se evidencie na prosódia de Paulo Arantes, pode ser também depreendido de um momento singular de $O$ Circuito dos Afetos, em que Safatle busca complementar o conceito de populismo formulado por Laclau. A discussão, que aparentemente se trava em termos puramente filosófico-conceituais, culmina na afirmação da exemplaridade do caso lulista - motivo pelo qual a citação, apesar de longa, se faz imperativa:

"No entanto, Laclau deveria explorar com mais sistematicidade a natureza profundamente ambígua das estratégias populistas e sua necessária limitação. Ambiguidade entendida (...) no sentido de uma oscilação contínua, interna a todo movimento populista, entre transformação e paralisia. Por sustentar a necessidade de sujeitos políticos se expressarem como povo constituído através 
de cadeias de equivalências entre demandas concretas muitas vezes contraditórias, o populismo é assombrado continuamente pelo risco da paralisia dos processos de transformação social devido ao fato de alcançarmos rapidamente um ponto de equilíbrio no qual demandas conflitantes começam a se vetar mutuamente. 0 populismo avança em situações nas quais há um cálculo possível que permite a várias e determinadas demandas conflitantes mais fortes serem, em algum nível, contempladas. No entanto, ele depara rapidamente com uma situação na qual processos de transformação se estancam devido ao equilíbrio impossível entre demandas conflitantes, o que faz do processo de liderança uma gestão contínua do imobilismo e da inércia, desviada pela construção pontual de antagonismos setorizados com grupos exteriores. Faz parte da dinâmica do populismo a presença desses momentos nos quais o imobilismo se justifica pela transformação da luta de classes em mero fantasma a assombrar, com ameaças de regressões e condições antigas de vulnerabilidade, os setores submetidos à liderança. Assim, consolida-se a dependência às figuras de liderança que já não são capazes de fazer o processo de transformação avançar, mas que tentam nos fazer acreditar que, se desaparecerem, elas poderiam nos levar à situação de perda das conquistas geradas. Figuras que a partir de então se perpetuarão através do retorno fatídico à mobilização libidinal do medo como afeto político. $\mathrm{O}$ caso brasileiro recente do esgotamento do lulismo é um exemplo quase didático nesse sentido" (2016a:84-5).

O caminho traçado acima por Safatle, que se inicia com a "necessária limitação" e termina no "esgotamento", é ilustrativo do modo como mesmo seu esforço recente de tentar conferir densidade conceitual ao populismo, pelo diálogo e crítica com a noção de Laclau, não escapa das mesmas armadilhas de sempre. Em certo sentido, aquilo que Safatle atribui à "dinâmica do populismo" poderia também ser concebido como simples modos de ser da política democrática: oscilações entre transformação e paralisia, riscos de paralisia e ameaças de regressões, demandas conflitantes que se vetam mutuamente, perda de conquistas. Nesse caso, a "natureza profundamente ambígua das estratégias populistas" teria algo que ver com a própria incerteza intrínseca ao ambiente democrático. Mas a centralidade conferida às "estratégias populistas" indica um retorno da ênfase no personalismo, point d'honneur das críticas do populismo. E mais do que isso: a argumentação do filósofo parece lidar com a implícita assunção de que haveria um "processo de transformação social" entendido quase como um hegeliano curso-do-mundo, por sobre o qual o "movimento populista" se anexaria como um corpo estranho e, eventualmente, parasitário, prenhe de artimanhas a criar falsos riscos, pueris assombrações e ameaças. Como se, de novo, o risco das regressões e da perda de conquistas não fosse uma virtualidade sempre possível da luta política, mas apenas um artifício retórico para os fins autocentrados da liderança populista.

Essa premissa da necessidade da transformação, inscrita na história, subjaz à afirmação dos limites e do esgotamento do lulismo como apenas mais um "caso", uma ilustração, do que seria a regra de ouro dos populismos - como se os impasses fossem sintomas da menor aderência do populismo de plantão ao espírito-do-mundo, sempre indutor do (e induzido pelo) "processo de transformação". Nesse sentido, os populismos seriam os portadores precários deste processo mais fundamental - e a crença de que regressões e paralisias se devem a manipulações retóricas ou a limitações necessárias da política populista apenas reafirma aquela premissa. No plano da política democrática, imobilismos por vezes expressam, de fato, momentos críticos e acirrados da luta de classes; no plano da política populista construído por Safatle, "o imobilismo se justifica pela transformação da luta de classes em mero fantasma a assombrar", ou seja, a luta de classes tornase elemento discursivo de justificações. Em outros termos, ela seria espectral, e falsa, quando faz recuar, e efetiva apenas quando condiz com aquele motor primeiro da história, a transformação. Assim, a derrota do populismo, entendida como "esgotamento", nunca será efeito concreto da luta 
de classes, mas sim emancipação de um invólucro mistificador - daí ela ser tratada como "derrota inevitável" (Safatle, 2016c), fruto de um "modelo em colapso" (2016b) 1 .

Também no que tange a mais esse colapso do populismo, Paulo Arantes ocupa o destacado lugar analítico de quem tematizou a queda desde os primeiros momentos da chegada do PT à presidência. Aqui, acompanhar brevemente a cronologia do precoce réquiem de Arantes ao Governo Lula será relevante para entendermos como se dá sua avaliação, a posteriori, do impeachment de Dilma Rousseff. Já em 2003, "Lula teria selado o seu destino" depois de "beijar a cruz" do FMI e de retomar a "agenda falida do período anterior" (Arantes, 2003:303). Reafirmando uma posição corrente entre os críticos de esquerda dos primeiros passos do PT no governo federal, Arantes condena o que seria uma "conversão suicida do Governo Lula à ortodoxia econômica" (Arantes, 2003:306). Deriva de sua leitura uma espécie de "colapso originário", que aparece nestes primeiros momentos do lulismo e cuja ênfase será redobrada a partir de 2005 com o "escândalo do mensalão".

Enquanto Safatle chega a reconhecer uma relativa especificidade no modo lulista de "compreender o necessário caráter indutor do Estado brasileiro no nosso desenvolvimento" (Safatle, 2012:14), Arantes, por sua vez, pouco ou nada concede, sendo a sua versão do "populismo lulista" uma mera adaptação do neoliberalismo dos anos 1990. Daí que, em 2005, diante da denúncia do suposto mensalão, os termos são ainda mais hiperbólicos: "dizer que o governo Lula acabou não deixa de ser um exagero piedoso, pois supõe que em algum momento ele tenha começado" (Arantes, 2007:253). Importa reconstituir a aspereza dos juízos emitidos no calor do momento: falase no "espantoso colapso do governo Lula", na "ruína moral e política do PT", no "naufrágio lulista" (Arantes, 2007:247) e projeta-se que o governo passaria então a "vegetar como o segundo mandato de FHC", vivendo de "espasmos populistas" (Arantes, 2007:255). Tais espasmos talvez sejam o fator que impulsionam o analista da conjuntura a arriscar uma comparação histórica entre os dois períodos populistas. Para Arantes, este colapso (detectado em 2005) representaria "a maior derrota da esquerda em toda a história do país", posto que teria se dado "pela pior das capitulações: sem combate e por adesão prévia ao programa do inimigo"; enquanto em 1964, "uma linha política equivocada foi sepultada por um golpe militar no contexto dramático da Guerra Fria, dando início ao declínio do ciclo comunista da esquerda brasileira" (Arantes, 2007:279). Tratar o golpe de 1964 como sepultamento de "uma linha política equivocada" constitui, vale reiterar, uma posição que vincula diretamente a perspectiva de Arantes ao paradigma do populismo, segundo o qual o colapso seria a um só tempo, em marcha dialética, uma tendência intrínseca do modelo e o preço a pagar pelo "equívoco político"2.

O acompanhamento cerrado da cronologia das intervenções de Paulo Arantes sobre o colapso originário do lulismo encerra-se com a projeção das eleições de 2006, onde uma eventual vitória do PT consagraria "o pior do novo populismo" e confiscaria "de vez a consciência política dos espoliados de sempre" (Arantes, 2007:271) - sendo desnecessário sublinhar o quanto a própria ideia de um confisco da consciência política reatualiza, em termos ainda mais demofóbicos, a crítica do velho populismo dos anos 1960.

Posteriormente, ao tratar do afastamento da presidenta Dilma, apenas um mês depois do fatídico 17 de abril de 2016, o filósofo retoma sua grande narrativa sobre a perpetuação dos termos de um modo extremo de dominação no país ao relativizar a adequação do uso da palavra "golpe" para lidar com os eventos daquele ano. Exclamar que "o PT é quem está consumando um projeto de

\footnotetext{
${ }^{1}$ Em seu livro mais recente, Só mais um esforço (2017), Safatle volta a lançar mão de noções caras ao paradigma do populismo. Nesse sentido, fala-se em um "horizonte populista perdido" após a queda do governo Dilma. E, mais sintomaticamente, constrói-se uma leitura em que "colapso" e "esgotamento" passam a transcender os horizontes do modelo populista. Do particular para o geral, teríamos um "esgotamento do lulismo" implicando o "esgotamento da esquerda", em um quadro de "esgotamento da Nova República" como sintoma nacional do fenômeno global de "colapso da democracia liberal" (Safatle, 2017, p. 58, 78, 106, 108, 119).

${ }^{2}$ A vinculação entre "erro" e "colapso" aparece também no tratamento que Roberto Schwarz dedica, em diversos textos, ao golpe de 1964. Sobre o "desenvolvimentismo" do pré-1964, por exemplo, Schwarz afirma em tom memorialístico: "os nossos olhos estritos notavam o caráter mais nacionalista do que socialista da pregação: tratava-se de um quadro claro de inconsequência, para o qual torcíamos o nariz. Não há dúvida de que a falta de rigor existia, e que em 64 foi preciso pagar por ela" (Schwarz, 1999, p. 92).
} 
Brasil Potência gerado por duas ditaduras" implica situar o suposto golpeado em linha de continuidade com os piores momentos da história política do país. Porque seria "esse Brasil Potência que nós somos chamados a defender quando nos contrapomos ao golpe", e porque "a palavra golpe pode ser legitimadora, nobilitadora", importa ao filósofo não se filiar àqueles que, aderindo à narrativa do golpe, constroem uma "tábua de salvação" histórica a quem, a seus olhos, não deveria de modo algum ser salvo (Arantes, 2016). "Quem é vítima de um golpe tem todas as razões do mundo", diz Arantes, e por isso conviria fugir de uma caracterização que confere razão àqueles atores políticos por ele mesmo identificados como originariamente decaídos. Sua tese, que chamamos aqui de "colapso originário" e cujo desenvolvimento acompanhamos acima, culmina com a estridente recusa em entoar o coro contra o golpe.

A ampla aceitação, ao menos nas hostes intelectuais, disto que identificamos como uma retomada do paradigma do populismo pode ainda ser atestada por breve incursão nas intervenções recentes de Ruy Fausto. Adotando uma perspectiva política diferente com relação aos outros dois filósofos estudados, Fausto valoriza a democracia representativa e, com isso, transcende tanto o estreito horizonte frankfurtiano da crítica de Safatle quanto a linearidade faoriana do olhar histórico de Arantes. Daí o interesse em agregá-lo no contexto de um panorama sobre a retomada do paradigma, como expressão da diferença interna de seus adeptos e da plasticidade de sua aplicação. Adepto do controverso conceito de totalitarismo, e crítico contumaz de sua história, Ruy Fausto inscreve o "populismo de esquerda" como uma das três patologias, ao lado do "neototalitarismo" e do "adesismo" (2016a), que teriam acometido a esquerda ao longo do século XX. Esta classificação, que desde logo pressupõe uma antinomia entre a forma reta e as "formas aberrantes", a normalidade e as "doenças" (Fausto, 2017:11), é construída de um lugar privilegiado reclamado para a "esquerda autêntica", que seria portadora de um "discurso de verdade" (2016a). Dentre outros atributos, a posse deste vago "respeito pela verdade", tratado pelo filósofo sem maiores reticências com relação à difícil objetividade que atravessa o plano da prática (e da ciência) política, oporia a autenticidade da esquerda frente à "fala populista irresponsável diante da verdade [que] nos condena à derrota" (2016a). Assentada essa antinomia básica do pensamento político de Fausto, que deriva diretamente a verdade da retidão e da autenticidade e, por conseguinte, vincula a mentira e o vício à patologia e a deformação, tem-se uma definição do "populismo de esquerda". Este deve abranger ao menos duas de três características fundamentais, quais sejam: liderança carismática autoritária; política de satisfação de interesses de classes mais ou menos antagônicas; laxismo na administração da riqueza pública (2016a).

A patologia, identificada genericamente no âmbito da esquerda no século $X X$, é diagnosticada no caso brasileiro. Diante das dificuldades de enquadrar perfeitamente o caso petista nos critérios delineados, fala-se de um "populismo atípico" ou de um "populismo sui generis" (2016a). Mas essa aparente relativização da aplicabilidade direta da noção para o caso brasileiro logo desfaz-se na afirmação de que "a prática petista foi e é uma prática patológica e, nesse sentido, comparável mutatis mutandis à prática dos neototalitários [leninistas-stalinistas] e à dos reformistasadesistas [social-democratas]" (2016a). Alçado ao patamar patológico dos totalitarismos, o populismo, com suas variações locais, deve ser objeto de um "combate essencial para a esquerda". Ainda assim, Fausto distancia-se das restrições vocabulares de Paulo Arantes ao atribuir o caráter de "golpe" ao impeachment de Dilma Rousseff - um golpe, bem entendido, que teria sido, ao menos em parte, "resultado da crise do populismo sui generis petista" (2016a).

A ideia de um "esgotamento de ciclo" do PT, correlata do "colapso" enquanto termo dileto dos críticos do populismo, também comparece nas análises de Fausto (2016b e Fausto e Araújo, 2017). E, finalmente, é a sua adesão aos termos da primeira crítica marxista do populismo no Brasil que mais aproxima sua perspectiva daquelas de Safatle e Arantes: não se põe em questão, em Fausto, o acerto do diagnóstico sobre a "república populista" de 1946. Pelo contrário, sua leitura mais abrangente sobre a trajetória do Partido dos Trabalhadores se constrói precisamente por uma sucessão de afastamento e reconciliação do PT com os fundamentos do populismo.

É interessante destacar, antes de mais nada, que ao calibrar sua crítica à onda neoliberal nos anos 1990, o PT parecia ter conseguido unir aquilo que sempre esteve separado na política brasileira: um projeto social ligado a reivindicações democráticas e uma firme posição de recusa de toda sorte de corrupção administrativa ou outra. De fato, só os políticos populistas do regime de 1946, 
juntamente com seus respectivos partidos, defendiam - ou apareciam como se defendessem - um programa social. Mas eles eram, em geral, ou corruptos, ou suspeitos de defender uma agenda autoritária (em todo caso, pouco democrática). (...) Ao assumir o comando da política nacional, o PT trouxe de volta a disjunção legada pelo populismo pré-1964, lançando um programa progressista do ponto de vista social mas, ao mesmo tempo, mergulhando na corrupção e fazendo vista grossa à ditadura dos irmãos Castro e às práticas autoritárias do regime de Hugo Chávez (Fausto e Araújo, 2017:177-178).

A narrativa da reconciliação entre o PT e a tradição nacional-desenvolvimentista é corrente entre as análises recentes dos anos do lulismo. $\mathrm{E}$ trata-se, de fato, de tema profícuo para pesquisas sobre a história política recente do país. A nosso ver, contudo, ao naturalizar o populismo como um dado do regime de 1946, atribuindo indeterminadamente "corrupção" e "autoritarismo" aos atores políticos de então, Fausto termina por enviesar sua leitura da prática política do período lulista. Estabelecido esse viés "antipopulista", voltam o "mar de lama" e a crítica genérica de filiações autoritárias no plano internacional - elementos, em nada insignificantes, da própria disputa política que acelerou a derrota da esquerda (tanto em 1964 quanto em 2016). A mesma ambiguidade explícita na posição de Arantes com relação aos eventos de 1964, entendidos como "derrota de uma linha política equivocada", reaparece em Fausto na imagem hiperbolizada da extirpação de uma patologia que, por si só, parece longe de induzir à emergência de um novo corpo, autêntico e são. Tal recusa em afirmar uma linha de interpretação que vincule empaticamente o crítico à esquerda derrotada é comum aos dois momentos históricos e figura, pois, como eloquente sintoma dos limites do paradigma do populismo.

\section{Considerações finais}

Em influente artigo de 2013, Marco D'Eramo explora o fato de que o termo populismo costuma ser mobilizado, tanto no discurso acadêmico quanto nas esferas públicas de diversos países ocidentais, como se seu conteúdo fosse auto-evidente e devesse ser repudiado com "ansiosa unanimidade", apesar de ninguém saber ao certo o que o termo quer dizer (D'Eramo, 2013, p.5). Nos sugestivos apontamentos do sociólogo italiano, sobressai a ideia de que haveria algo de sintomático quando os autointitulados defensores da democracia saem à caça dos populismos, reais ou imaginários, sem, contudo, jamais enunciar a palavra "povo"; para ele, "those who eviscerate democracy are the most inclined to see threats to it everywhere" (Idem, p.28). Em sentido análogo, Jacques Rancière atribui a proliferação das alusões ao populismo a uma renitente reação oligárquica contra a democracia. Segundo o filósofo francês, populismo seria o termo que, a um só tempo, "mascara e revela a grande aspiração da oligarquia: governar sem povo, (...) governar sem política" (Rancière, 2014, p.102).

Essa tensão entre a crítica dos populismos e seu aparente, ou furtivo, conteúdo demofóbico comparece também no contexto brasileiro que analisamos ao longo deste artigo. Tratou-se de um caso específico em que, como argumentamos, a formação de um paradigma, de extração marxista, consolidou à esquerda certas linhas de interpretação sobre a assim chamada "república populista", de 1946 a 1964, cujos pressupostos voltaram a ser mobilizados por diversos autores que se debruçaram sobre a política brasileira contemporânea e, mais especificamente, sobre a experiência lulista, ora interrompida, de 2003 a 2016.

Como se sabe, o paradigma do populismo não foi forjado no gabinete, como peça de neutra observação científica, mas sim no conturbado contexto da luta política no imediato pré-golpe de 1964. Nesse sentido, ainda que os três pressupostos fundamentais do paradigma tenham sua elaboração mais bem acabada na obra de Francisco Weffort, interessa reiterar que há elos entre esta gênese teórica e aquela, menos aludida, gênese política. Pudemos, então, observar como os pressupostos do paradigma passam a ser mobilizados, quarenta anos depois de sua formulação original, no conflito hermenêutico sobre os sentidos do lulismo. Ainda que esta querela envolva tantos outros intelectuais, a serem oportunamente incluídos em estudos ulteriores, o recorte de leituras numa chave filosófico-política justificou a análise das obras recentes de três especialistas da dialética: Vladimir Safatle, Paulo Arantes e Ruy Fausto. Ainda que diversas entre si, vimos como as 
obras partem da "linguagem emprestada" da crítica marxista do populismo e, tematizando o presente na chave da repetição, reincidem em muitos dos limites analíticos próprios ao paradigma. Se no registro da teoria crítica contemporânea a estrita perspectiva classista de Weffort soa fora de lugar e não é teorizada nos mesmos termos, mesmo assim persistem as premissas acerca de um regime essencialmente inconsistente de conciliação fadado, por necessidade histórica, ao colapso.

Para além do imperativo de ampliar a investigação das interpretações do Brasil contemporâneo que reproduzem (Francisco de Oliveira, Ruy Braga, Ricardo Antunes, Armando Boito Jr.) ou suprassumem (André Singer) o paradigma do populismo, este estudo aponta para outro profícuo desdobramento: pensar como certos paradigmas, como o do populismo, se entrecruzam transversal e promiscuamente com as linhagens do pensamento político brasileiro, promovendo as "polarizações ambíguas ou conciliações produtivas, sublimes coerências ou ecletismos maltemperados" (Brandão, 2007, p.39) que tornam instigante e intrincado o estudo do pensamento político na periferia do capitalismo. Até porque a aversão demofóbica ao populismo não se restringe a teóricos e analistas do campo da esquerda, constituindo-se em objeto privilegiado para a observação de confluências inauditas entre marxismo e liberalismo no ambiente ideológico brasileiro - tema espinhoso, acima apenas tangenciado, que exige aprofundamentos ulteriores.

(Recebido para publicação em maio de 2018)

(Reapresentado em julho de 2018)

(Aprovado para publicação em julho de 2018)

\section{Cite este artigo}

LIMA, Pedro Luiz; MEDEIROS, Josué. Aquém do Lulismo: notas críticas sobre a atual reprodução do paradigma do populismo por filósofos políticos brasileiros. Revista

Estudos Políticos: a publicação semestral do Laboratório de Estudos Hum(e)anos (UFF). Rio de Janeiro, Vol. 9 |N.1, pp. $177-189$, julho de 2018. Disponível em:

http://revistaestudospoliticos.com/

\section{Bibliografia}

ARANTES, Paulo Eduardo. Zero à Esquerda. São Paulo: Conrad Livros, 2003.

ARANTES, Paulo Eduardo. Extinção. São Paulo: Boitempo, 2007.

ARANTES, Paulo Eduardo. O novo tempo do mundo. São

Paulo: Boitempo, 2014.

ARANTES, Paulo Eduardo. Participação no colóquio

"Caminhos da esquerda diante do golpe". USP, 30 de maio de 2016.

BARBOSA FILHO, Rubem. Populismo - Uma revisão crítica. Dissertação de mestrado em Ciência Política. UFJF, 1980.

BRANDÃO, Gildo Marçal. Linhagens do pensamento político brasileiro. São Paulo: Hucitec, 2007.

CARDOSO, Fernando Henrique. Empresário Industrial e Desenvolvimento Econômico no Brasil. São Paulo: Difusão Europeia do Livro, 1964. 
D'ERAMO, Marco. "Populism and the new oligarchy". In: New Left Review, n. 82, agosto de 2013.

FAUSTO, Ruy. "Reconstruir a esquerda". In: Piauí. São Paulo, outubro de 2016a.

FAUSTO, Ruy. "Notas críticas a propósito de debates e pronunciamentos de esquerda sobre a situação política no Brasil". In: Revista Fevereiro, n. 9, abril de 2016b.

FAUSTO, Ruy. Caminhos da esquerda: elementos para uma reconstrução. São Paulo: Cia das Letras, 2017.

FAUSTO, Ruy e Araújo, Cicero. "Sombras e luzes à esquerda". In: Fornazieri et alii (orgs). A crise das esquerdas. Rio de Janeiro: Civilização Brasileira, 2017. FERREIRA, Jorge (org.) O populismo e sua história: debate e crítica. Rio de Janeiro: Civilização brasileira, 2001.

GOMES, Angela de Castro. "O populismo e as ciências sociais no Brasil: notas sobre a trajetória de um conceito". In: FERREIRA, J (org). O populismo e sua história: Debate e crítica. Rio de Janeiro: Civilização Brasileira, 2001, p. 17-57. GOMES, Angela de Castro. A invenção do trabalhismo. Rio de Janeiro: FGV, 2005.

GUIMARÃES, Cesar. "Vargas e Kubitschek: a longa distância entre a Petrobras e Brasília". In: Carvalho, Maria Alice Rezende de (org). República no Catete. Rio de Janeiro: Museu da República, 2001, p. 155-175.

IANNI, Octávio; Cohn, G; Singer, P; Weffort, F. Política e Revolução Social no Brasil. Rio de Janeiro: Civilização Brasileira, 1965.

IANNI, Octávio. O colapso do populismo no Brasil. Rio de Janeiro: Civilização Brasileira, 1968.

IANNI, Octávio. A formação do Estado populista na América Latina. Rio de Janeiro: Civilização Brasileira, 1974.

LACLAU, Ernesto. On populist reason. Londres: Verso, 2005. MAIA, João Marcelo Ehlert. A História de um Conceito: Populismo no Brasil. Dissertação de mestrado em Ciência Política. IUPERJ, 2001.

MARX, Karl. O Dezoito brumário de Luís Bonaparte. São Paulo: Boitempo, 2011.

PERLATTO, Fernando e Chaves, Daniel (orgs.). Repensar os populismos na América do Sul. Macapá: Editora da UNIFAP, 2016.

RANCIÈRE, Jacques. O ódio à democracia. São Paulo: Boitempo, 2014.

SAFATLE, V.P. "O mito do desenvolvimento econômico na era Lula". In: Pedro de Souza. (Org.). Brasil, Sociedade em Movimento. São Paulo: Paz e Terra, 2015, p. 71-76.

SAFATLE, V.P. O circuito dos afetos. São Paulo: Cosac e Naify, 2016a.

SAFATLE, V.P. "Entre a oligarquia e o populismo". In: Folha de São Paulo, edição de 29 de abril de 2016.

SAFATLE. V.P. Só mais um esforço. São Paulo: Três Estrelas, 2017.

SCHWARZ, Roberto. Sequências brasileiras. São Paulo:

Companhia das Letras, 1999. 
WEFFORT, Francisco. "Raízes sociais do populismo em São Paulo". In: Revista Civilização Brasileira. Rio de Janeiro, n. 2, 1965.

WEFFORT, Francisco. "Política de massas". In: Ianni, Octávio; Cohn, G; Singer, P; Weffort, F. Política e Revolução Social no Brasil. Rio de Janeiro: Civilização Brasileira, 1965b. WEFFORT, Francisco. O populismo na política brasileira. Rio de Janeiro: Civilização Brasileira, 1978.

WERNECK VIANNA, Luiz Jorge. Liberalismo e Sindicato no Brasil. Rio de Janeiro: Ed Paz e Terra, 1976.

WERNECK VIANNA, Luiz Jorge. "Estudos sobre o sindicalismo e o movimento operário: resenha de algumas tendências". In: CERQUEIRA, E (org). O que se deve ler em Ciências Sociais no Brasil. São Paulo: Cortez/Anpocs, 1986.

WERNECK VIANNA, Luiz Jorge. Weber e a interpretação do Brasil. In: Revista Novos Estudos. Rio de Janeiro, 1999, p.33-47.

WERNECK VIANNA, Luiz Jorge. A Revolução Passiva. Iberismo e americanismo no Brasil. Rio de Janeiro: Ed Revan, 2004. 